Prepared in cooperation with the Mid-Columbia Fisheries Enhancement Group

\title{
Salmon Habitat Assessment for Conservation Planning in the Lower White Salmon River, Washington
}

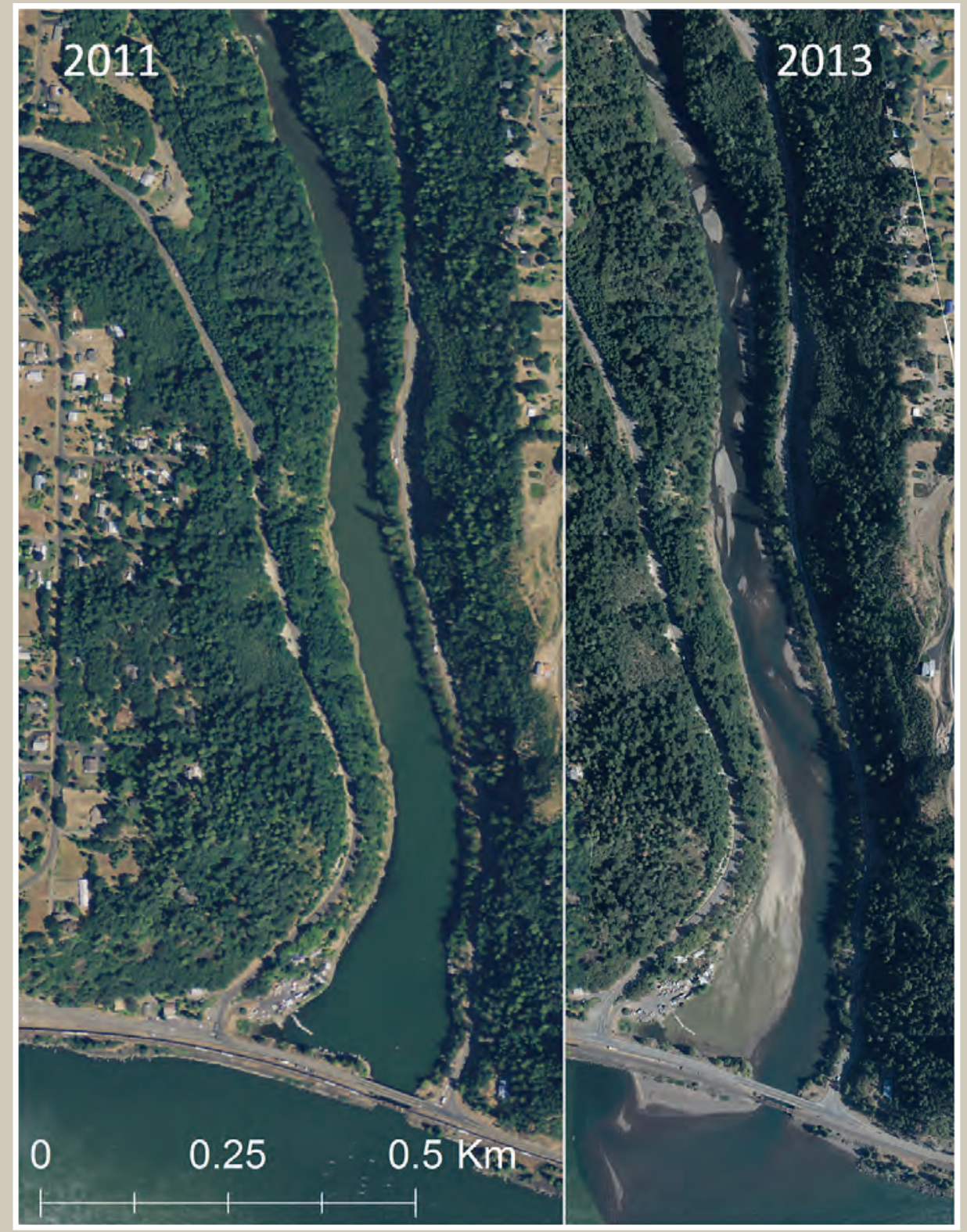

Open-File Report 2015-1100

U.S. Department of the Interior

U.S. Geological Survey 
Cover: Aerial photographs of the lower 1 mile of the White Salmon River, Washington, and the confluence with the Columbia River. The 2011 imagery (left-side photograph) is from the National Agriculture Imagery Program, U.S. Department of Agriculture-Farm Service Agency Aerial Photography Field Office and the 2013 (right-side photograph) imagery is from PacifiCorp aerial flight on August 6, 2013 . 


\section{Salmon Habitat Assessment for Conservation Planning in the Lower White Salmon River, Washington}

By Jill M. Hardiman and M. Brady Allen

Prepared in cooperation with the Mid-Columbia Fisheries Enhancement Group

Open-File Report 2015-1100

U.S. Department of the Interior

U.S. Geological Survey 


\section{U.S. Department of the Interior \\ SALLY JEWELL, Secretary}

\section{U.S. Geological Survey \\ Suzette M. Kimball, Acting Director}

U.S. Geological Survey, Reston, Virginia: 2015

For more information on the USGS—-the Federal source for science about the Earth, its natural and living resources, natural hazards, and the environment-visit http://www.usgs.gov/ or call 1-888-ASK-USGS (1-888-275-8747).

For an overview of USGS information products, including maps, imagery, and publications, visit http://www.usgs.gov/pubprod/.

Any use of trade, firm, or product names is for descriptive purposes only and does not imply endorsement by the U.S. Government.

Although this information product, for the most part, is in the public domain, it also may contain copyrighted materials as noted in the text. Permission to reproduce copyrighted items must be secured from the copyright owner.

Suggested citation:

Hardiman, J.M., and Allen, M.B., 2015, Salmon habitat assessment for conservation planning in the lower White Salmon River, Washington: U.S. Geological Survey Open-File Report 2015-1100, 24 p., http://dx.doi.org/10.3133/ofr20151100.

ISSN 2331-1258 (online) 


\section{Contents}

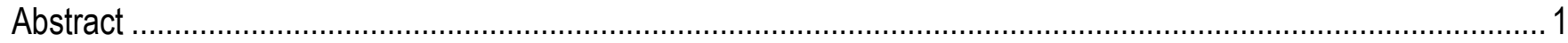

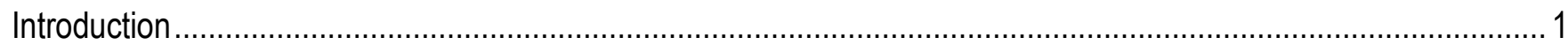

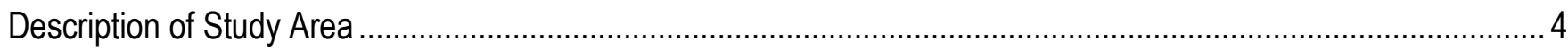

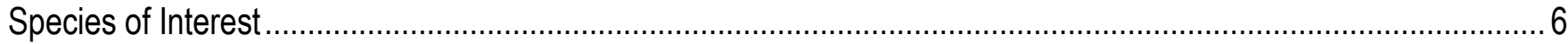

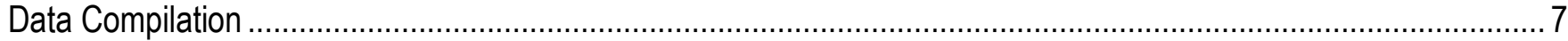

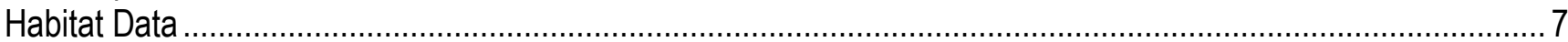

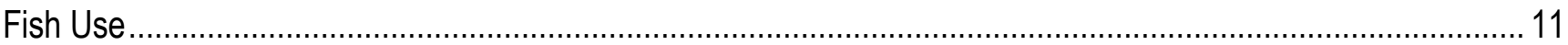

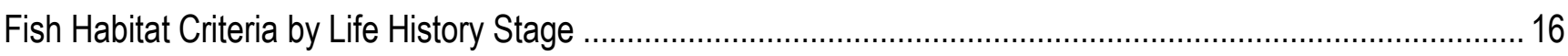

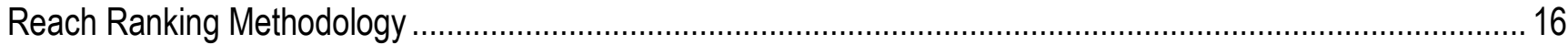

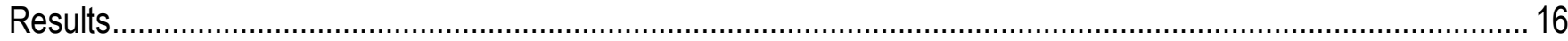

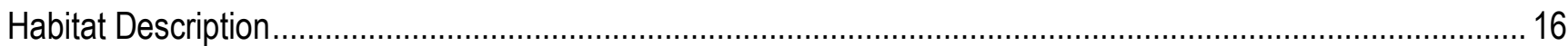

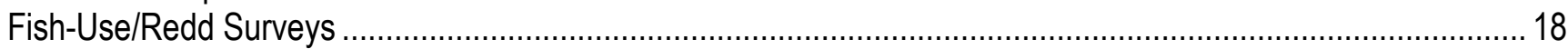

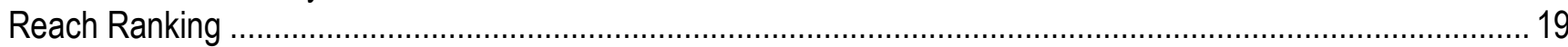

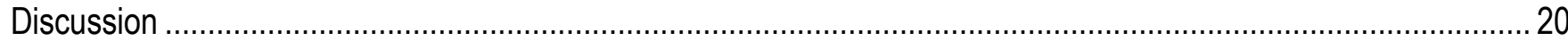

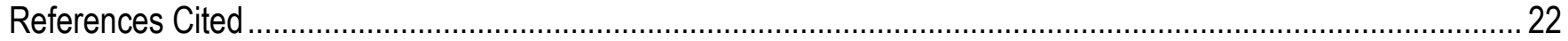

\section{Figures}

Figure 1. Map showing study area of the lower 6 miles of the White Salmon River, Washington .......................... 3

Figure 2. Graph showing daily mean discharge at the U.S. Geological Survey streamgage (14123500) at river mile 1.9, White Salmon River, Washington

Figure 3. Map showing digital elevation model of the study area from lidar flight conducted in August 2013, White Salmon River, Washington.... 8

Figure 4. Map showing near-shore bank slope in degrees in the lower White Salmon River, Washington .............. 9

Figure 5. Map showing water-surface elevation and study area reach breaks in the lower White Salmon River, Washington

Figure 6. Map showing change from 2012 to 2013 in gravel bar location and size in the first river mile of the White Salmon River, Washington

Figure 7. Map showing Chinook salmon redd survey results from U.S. Fish and Wildlife Service surveys during autumn 2012 and from Washington Department of Fish and Wildlife surveys of Chinook salmon redds in 2013 in the lower White Salmon River, Washington

Figure 8. Map showing Chinook salmon redd survey results from U.S. Fish and Wildlife Service surveys during autumn 2012 and from Washington Department of Fish and Wildlife surveys of Chinook salmon redds in 2013 in the lower White Salmon River, Washington

\section{Tables}

Table 1. Endangered Species Act listed Evolutionarily Significant Unit/Distinct Population Segment (ESU/DPS) salmonids in the White Salmon River.

Table 2. Descriptions of reach divisions for salmon habitat assessment in the Lower White Salmon River, Washington

Table 3. Reach prioritization for the White Salmon River based on redd data from 2012 and 2013. 


\section{Conversion Factors}

Inch/Pound to International System of Units

\begin{tabular}{lcl}
\hline & Multiply & To obtain \\
\hline mile $(\mathrm{mi})$ & Length & \\
\hline & 1.609 & kilometer $(\mathrm{km})$ \\
\hline acre & Area & \\
acre & 4,047 & square meter $\left(\mathrm{m}^{2}\right)$ \\
& 0.004047 & square kilometer $\left(\mathrm{km}^{2}\right)$ \\
\hline cubic foot per second $\left(\mathrm{ft}^{3} / \mathrm{s}\right)$ & Flow rate & cubic meter per second $\left(\mathrm{m}^{3} / \mathrm{s}\right)$ \\
\hline & 0.02832 & \\
\hline cubic foot $\left(\mathrm{ft}^{3}\right)$ & Volume & cubic meter $\left(\mathrm{m}^{3}\right)$ \\
\hline
\end{tabular}

International System of Units to Inch/Pound

\begin{tabular}{|c|c|c|}
\hline Multiply & By & To obtain \\
\hline \multicolumn{3}{|c|}{ Length } \\
\hline kilometer $(\mathrm{km})$ & 0.6214 & mile (mi) \\
\hline \multicolumn{3}{|c|}{ Volume } \\
\hline cubic meter $\left(\mathrm{m}^{3}\right)$ & 35.31 & cubic foot $\left(\mathrm{ft}^{3}\right)$ \\
\hline \multicolumn{3}{|c|}{ Flow rate } \\
\hline cubic meter per second $\left(\mathrm{m}^{3} / \mathrm{s}\right)$ & 35.31 & cubic foot per second $\left(\mathrm{ft}^{3} / \mathrm{s}\right)$ \\
\hline
\end{tabular}

Temperature in degrees Celsius $\left({ }^{\circ} \mathrm{C}\right)$ may be converted to degrees Fahrenheit $\left({ }^{\circ} \mathrm{F}\right)$ as follows:

$$
{ }^{\circ} \mathrm{F}=\left(1.8 \mathrm{x}^{\circ} \mathrm{C}\right)+32
$$




\title{
Salmon Habitat Assessment for Conservation Planning in the Lower White Salmon River, Washington
}

\author{
By Jill M. Hardiman and M. Brady Allen
}

\begin{abstract}
In 2011, Condit Dam was removed from the White Salmon River, Washington. Since dam removal, there has been interest among scientists (State and Federal), Tribes, non-profit organizations, and the general public in assessing Pacific salmon habitat and use in the White Salmon River for conservation planning and potential fishery management actions. The study area extended from the lower 6 miles of the White Salmon River to the confluence with the Columbia River, including the former reservoir area. The Mid-Columbia Fisheries Enhancement Group received a grant to initiate efforts to plan for salmon habitat protection in the lower 6 river miles of the White Salmon River. As part of efforts by the Mid-Columbia Fisheries Enhancement Group to conduct conservation planning, the U.S. Geological Survey (USGS) used current and historical habitat information to assist in the planning process. The USGS compiled existing georeferenced habitat data into a Geographic Information System to identify areas of high quality habitat for salmon, potential areas for restoration/improvement, and areas that could be threatened. The primary sources of georeferenced data for this project include a lidar flight contracted by PacifiCorp, bathymetry from USGS, and fall Chinook salmon redd surveys from the U.S. Fish and Wildlife Service and Washington Department of Fish and Wildlife. Redd observations provided support that the study area is a migratory corridor for salmon and steelhead and that the lowest 2-3 miles had the highest concentration of documented fall Chinook salmon redds. The study area has potential for restoration/conservation areas to improve/conserve salmon habitat.
\end{abstract}

\section{Introduction}

The White Salmon River became free-flowing on October 26, 2011, after the breaching of Condit Dam. The Condit Hydroelectric Project was constructed in 1912 and 1913 at river mile (RM) 3.3 (river km 5.3) of the White Salmon River in Klickitat and Skamania Counties, Washington. The dam blocked fish passage for nearly a century prior to breaching. Dam removal was completed on September 14, 2012. Mitigation and restoration efforts, including sediment stabilization and re-vegetation of the newly exposed reservoir sediment, are ongoing (Greenworks and others, 2011; Inter-Fluve and others, 2011). The White Salmon watershed is part of both of Washington State's Lower Columbia River (LCR) salmon recovery domain and the Middle Columbia River (MCR) Steelhead Recovery subdomain, as well as the State's Water Resource Inventory Area (WRIA) 29b (Cowan, 1999; National Marine Fisheries Service, 2013; Washington State Department of Ecology, 2015). Land use in the 
lower White Salmon River includes commercial timber, irrigated cropland, orchards, and residential (Northwest Power and Conservation Council, 2004). Additionally, this area is heavily used for recreation by both private and commercial interests (rafting, kayaking, fishing, and others), including an in-lieu boat launch for Tribal fishing rights, and is part of the Columbia Gorge National Scenic Area (Columbia River Gorge Commission, 1991). Approximately $29 \mathrm{mi}$ of the White Salmon River are classified as Wild and Scenic, including the section from the town of BZ Corner (RM 12.4) to its confluence with Buck Creek at RM 5 (U.S. Forest Service, 1991, 2015). The White Salmon River has historically supported steelhead trout, spring and fall Chinook, coho, and chum salmon runs (Lane and Lane Associates, 1981; Cowan, 1999; National Marine Fisheries Service, 2013).

The removal of Condit Dam has expanded access to anadromous species to the upper White Salmon River and dramatically changed the habitat from a reservoir upstream of Condit Dam to a freeflowing river. The removal also resulted in new shorelines, steep banks, and exposed land area, particularly in the region of the former Northwestern Lake (reservoir formed by Condit Dam; Wilcox and others, 2014). Currently (2015), the river is in a state of flux, with riparian re-vegetation, sediment and gravel transport towards the lower sections and the confluence with the Columbia River, and changing gravel bars with high water events (J. Hatten, U.S. Geological Survey, written commun., 2014). Furthermore, a newly formed delta has appeared at the mouth of the White Salmon River at the confluence with the Columbia River (fig. 1). The newly exposed lands and steep banks in the former Northwestern Lake area are undergoing restoration efforts such as revegetation, some completed bank stabilization efforts, and large woody debris placements (JR Merit Industrial Contractors, 2013; Riverbend Engineering, LLC and JR Merit Industrial Contractors, 2013). The western shoreline in this region is used by cabin owners who lease their land from PacifiCorp, the primary landowner (500-600 acres) in the lower 6 river miles of the White Salmon River. The Mid-Columbia Fisheries Enhancement Group received a grant to initiate efforts to plan for salmon habitat protection in the lower 6 river miles of the White Salmon River. The primary objectives of the planning grant were to identify key habitat areas for salmonids that warrant protection, identify potential risks to these habitats, and involve stakeholders in discussions of salmon habitat protection strategies and issues. This report will focus on the results of the salmon habitat assessment conducted by the USGS.

The USGS and other agencies have provided habitat data and fish-use information for this assessment. This work focused on compiling and summarizing existing data and presenting new data, such as the lidar and orthophoto imagery provided by PacifiCorp from a flight conducted in August 2013. Lidar is a remote sensing technology to measure distance by illuminating a target with a laser and analyzing the reflected light, the results are used to make high-resolution maps. Monitoring information and spatial information from various habitat surveys were reviewed and incorporated into a Geographic Information System (GIS). Chinook salmon spawning survey data summaries from 2012 were provided by U.S. Fish and Wildlife Service (USFWS; Engle and others, 2013) and the Washington Department of Fish and Wildlife (WDFW) provided the Chinook salmon spawning data for 2013 and 2014 (WDFW, unpub. data, 2015). Additionally, this habitat assessment will be made within the context of the various life history stages of the salmonids historically present in this system. This document will provide an overview of the status of the salmonid habitat based on this existing information and will identify data gaps, or where additional information would better inform salmonid habitat needs. 


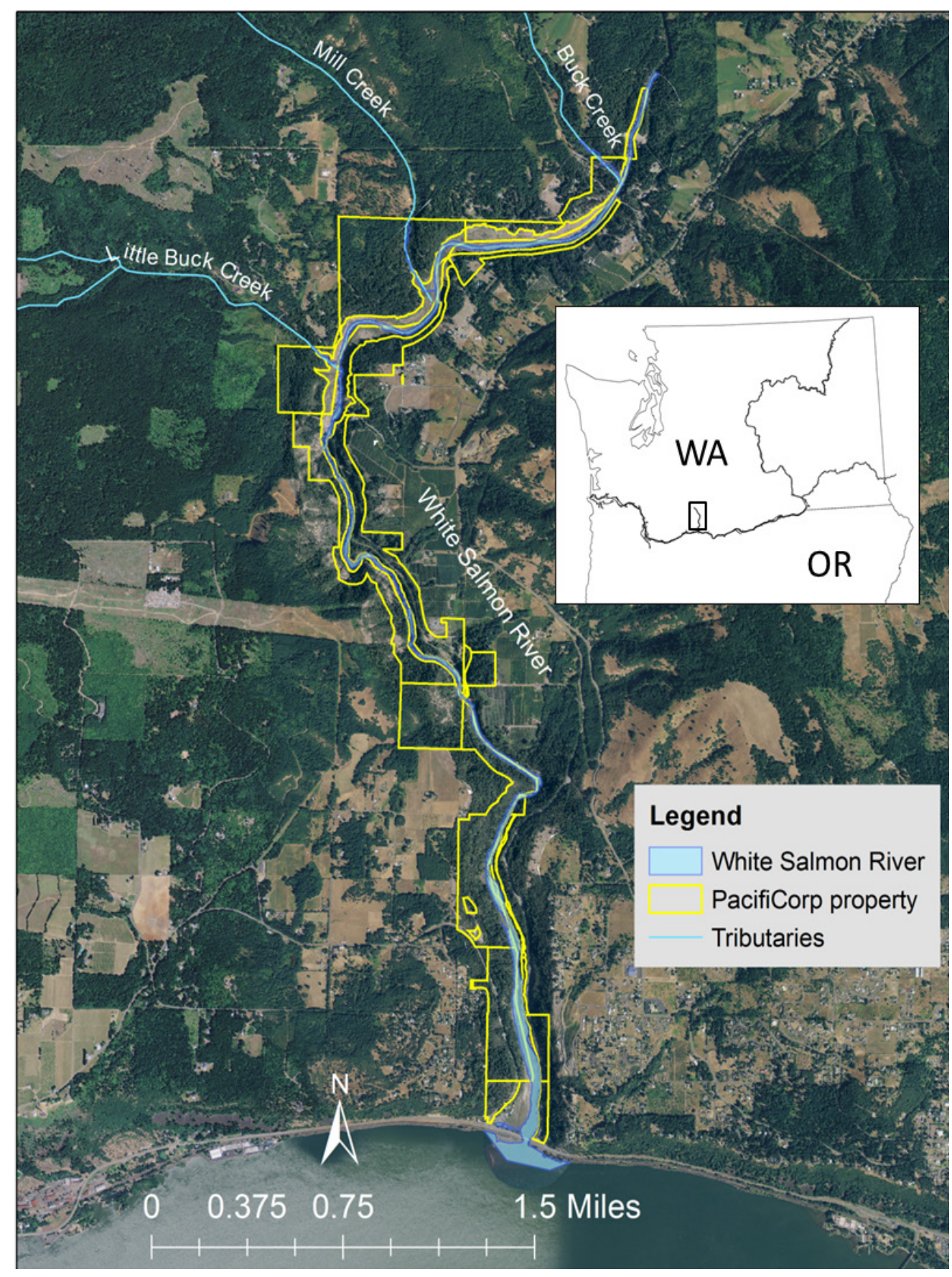

Figure 1. Map showing study area of the lower 6 miles of the White Salmon River, Washington. Yellow lines indicate property owned by PacifiCorp. 


\section{Description of Study Area}

The White Salmon River drains approximately $386 \mathrm{mi}^{2}$ of Klickitat, Yakima, and Skamania Counties in south-central Washington (Haring, 2003). The topography of the surrounding area is highly varied, including mountainous terrain, deeply incised canyons, rolling hills and low-gradient valley floors (Northwest Power and Conservation Council, 2004; National Marine Fisheries Service, 2013). The geographic area of interest is the lower 6 river miles of the White Salmon River (fig. 1) to the confluence with the Columbia River. The primary landowner in this area is currently PacifiCorp, according to records from Klickitat and Skamania Counties (fig. 1). In general, the mainstem White Salmon River has good water quantity and quality (Haring, 2003; Northwest Power and Conservation Council, 2004; Allen and Connolly, 2005). The average annual precipitation is about 9.5 in. with most precipitation delivered in the form of rainfall or snow between October and March (Harring, 2003). Peak flows in the mainstem reflect snowmelt runoff, increasing from an average daily flow of $644 \mathrm{ft}^{3} / \mathrm{s}$ during the autumn to flows of 1,538 $\mathrm{ft}^{3} / \mathrm{s}$ in the spring (USGS streamgage 14123500; Haring, 2003). Water temperatures remain cold with maximum and minimum temperatures and dissolved oxygen levels within optimal levels for salmonids, and river flow is maintained by cold springs and seeps coming from high-altitude snowmelt throughout the summer (fig. 2; Allen and Connolly, 2005). With the removal of Condit Dam, the characteristics of the lower river are changing now that natural watershed processes of large woody debris and gravel recruitment to the lower reaches have been restored. The amount of time these watershed processes take to reach equilibrium is unknown. At the time Condit Dam was breached, it was estimated that 63.6 million $\mathrm{ft}^{3}\left(1.8\right.$ million $\left.\mathrm{m}^{3}\right)$ of reservoir sediment had been impounded behind the dam (Wilcox and others, 2014). The dam was abruptly breached with an explosive blast with about a 16-ft-wide hole at the base of the dam that rapidly emptied the reservoir and much of the sediment consisting mostly of sand, silt, and clay (Wilcox and others, 2014). The outflow of silt, sand, and gravel filled pools throughout the lower river, created gravel bars, and a delta at the confluence with the Columbia River. To date, a large flood event (100year flood event is estimated at 13,596 ft 3 /s; Forest Energy Regulatory Commission, 1996) has not occurred since the breach. During winter 2013, only one flow event exceeded the 5-year flood recurrence interval (for November) threshold established for rapid assessment protocols to be implemented (Riverbend Engineering LLC and JR Merit Industrial Contractors, 2013). The lower river will likely be in a state of flux for the next few years as the river channel continues to stabilize and the riparian corridor re-establishes. 


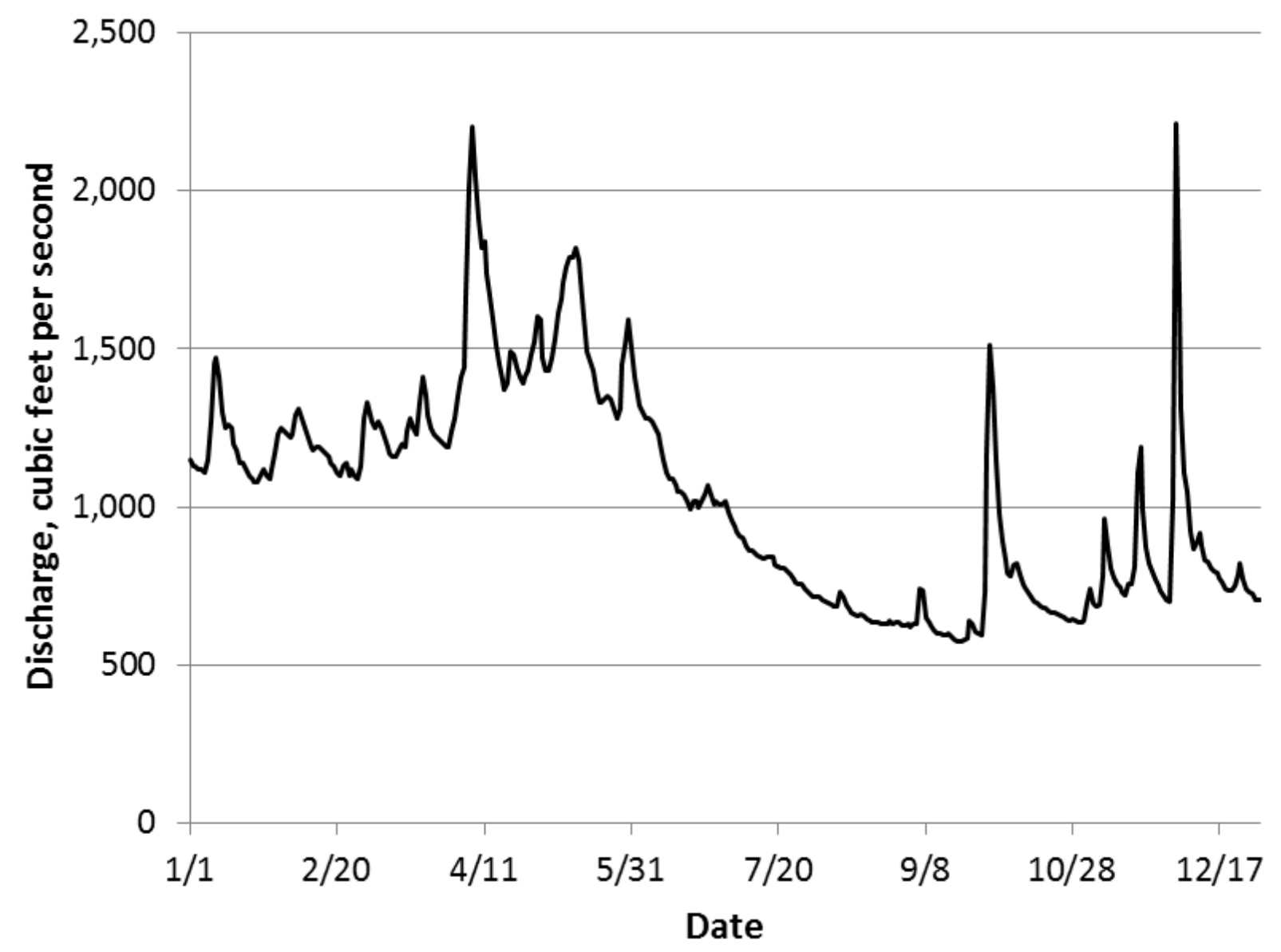

Figure 2. Graph showing daily mean discharge at the U.S. Geological Survey streamgage (14123500) at river mile 1.9, White Salmon River, Washington. Period of data calculation was from October 1, 2012, to September 30, 2014. 


\section{Species of Interest}

Historical fish production in the White Salmon River included five Endangered Species Act (ESA) listed Evolutionarily Significant Unit (ESU)/Distinct Population Segment (DPS) salmonid populations (table 1; National Marine Fisheries Service, 2013). The White Salmon River supported runs of MCR steelhead up to the falls at RM 16 and into Buck, Spring, Indian, and Rattlesnake Creeks (Northwest Power and Conservation Council, 2004). Based on spawning habitat accessibility and historical information, biologists assume that spring Chinook, coho, and chum salmon also were present in the watershed (Lane and Lane Associates, 1981; National Marine Fisheries Service, 2013). Husum Falls, at RM 7.6, was considered likely to be a barrier for fall Chinook salmon migration and a partial barrier for steelhead and coho salmon (Northwest Power and Conservation Council, 2004). Salmon and steelhead production was reduced significantly with the construction of Condit Dam, which blocked access to most of the historical range of spring and fall Chinook salmon, steelhead, and coho salmon populations. Currently (2015), the MCR steelhead population in the White Salmon River is considered functionally extirpated (Interior Columbia Technical Recovery Team, 2008) and also the LCR spring Chinook salmon, coho salmon, and the Columbia River chum salmon are considered extirpated (Myers and others, 2006). The National Marine Fisheries Service (NMFS) has developed a recovery plan for the ESA listed species in the White Salmon River (National Marine Fisheries Service, 2013).

Table 1. Endangered Species Act listed Evolutionarily Significant Unit/Distinct Population Segment (ESU/DPS) salmonids in the White Salmon River.

[LCR, Lower Columbia River; CR, Columbia River; MCR, Middle Columbia River.]

\begin{tabular}{|c|c|c|c|c|}
\hline Species & ESU/DPS & Status & \multicolumn{2}{|c|}{ Federal Register Notice } \\
\hline $\begin{array}{l}\text { Chinook Salmon (Oncorhynchus } \\
\text { tshawytscha) }\end{array}$ & LCR Chinook salmon & Threatened & 70 FR 37160 & $6 / 28 / 2005$ \\
\hline Coho salmon (O. kisutch) & LCR coho salmon & Threatened & 70 FR 37160 & $6 / 28 / 2005$ \\
\hline Chum salmon (O. keta) & CR chum salmon & Threatened & 70 FR 37160 & $6 / 28 / 2005$ \\
\hline Steelhead (O. mykiss) & MCR steelhead & Threatened & 71 FR 834 & $1 / 5 / 2006$ \\
\hline $\begin{array}{l}\text { Bull trout (Salvelinus } \\
\text { confluentus) }\end{array}$ & CR bull trout & Threatened & 63 FR 31647 & $6 / 10 / 1998$ \\
\hline Critical Habitat Designation & $\begin{array}{l}\text { LCR Chinook salmon, CR } \\
\text { chum salmon, LCR coho } \\
\text { salmon, MCR steelhead }\end{array}$ & & 70 FR 52630 & $9 / 2 / 2005$ \\
\hline Critical Habitat Designation & CR bull trout & & 75 FR 2269 & $1 / 14 / 2010$ \\
\hline
\end{tabular}




\section{Data Compilation}

\section{Habitat Data}

Datasets were compiled from a lidar flight conducted by PacifiCorp in August 2013. The USGS used the lidar data to create a digital elevation model (DEM) of the new river channel and surrounding area of the Lower White Salmon River (fig. 3). These data were also used to create datasets of streambank slope (fig. 4), and water-surface elevation in the river channel (fig. 5). The water-surface elevation data were used to delineate smaller reaches based on past Ecosystem Diagnosis and Treatment (EDT) model analysis (Allen and Connolly, 2005), changes in slopes, tributary confluences, and changes in habitat types, (that is, pool, riffle, run; table 2). PacifiCorp also shared digital orthophotogramatic imagery taken during this time, which the USGS incorporated into the GIS. We used this imagery to provide reference maps and create data layers, such as documentation of man-made and natural large woody debris (LWD) placement.

Table 2. Descriptions of reach divisions for salmon habitat assessment in the Lower White Salmon River, Washington.

\begin{tabular}{llccc}
\hline $\begin{array}{c}\text { Reach } \\
\text { name }\end{array}$ & \multicolumn{1}{c}{ Description } & $\begin{array}{c}\text { White Salmon } \\
\text { River miles }\end{array}$ & $\begin{array}{c}\text { Length } \\
\text { (foot) }\end{array}$ & $\begin{array}{c}\text { Slope } \\
\text { (percent) }\end{array}$ \\
\hline WS1 & Confluence to end of Bonneville influence & $0-1.1$ & 6,255 & 0.2 \\
WS2 & End of Bonneville influence to powerhouse & $1.1-2.2$ & 5,746 & 0.7 \\
WS3 & Powerhouse to Steelhead Falls & $2.2-2.6$ & 2,130 & 1.1 \\
WS4 & Steelhead Falls to mouth of Mill Creek & $2.6-4.2$ & 8,251 & 1.2 \\
WS5 & Mouth of Mill Creek to mouth of Buck Creek & $4.2-5.2$ & 5,172 & 0.7 \\
WS6 & Mouth of Buck Creek to end of study area (lidar data set) & $5.2-5.7$ & 2,284 & 0.7 \\
M1 & Mill Creek mouth to PacifiCorp property line & & 1,906 & 4.4 \\
B1 & Buck Creek mouth to PacifiCorp property line & & 715 & 4.3 \\
\hline
\end{tabular}




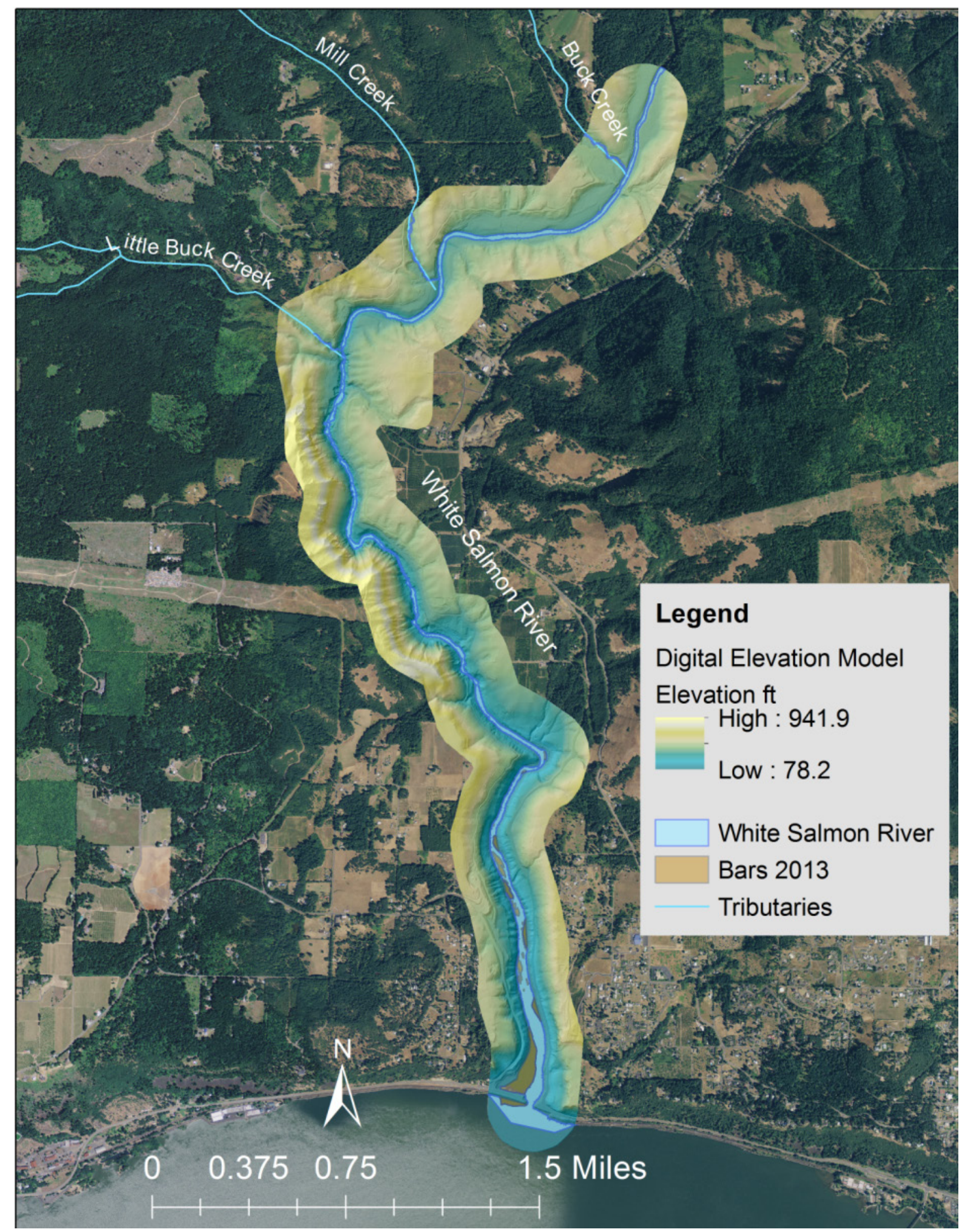

Figure 3. Map showing digital elevation model of the study area from lidar flight conducted in August 2013, White Salmon River, Washington. 


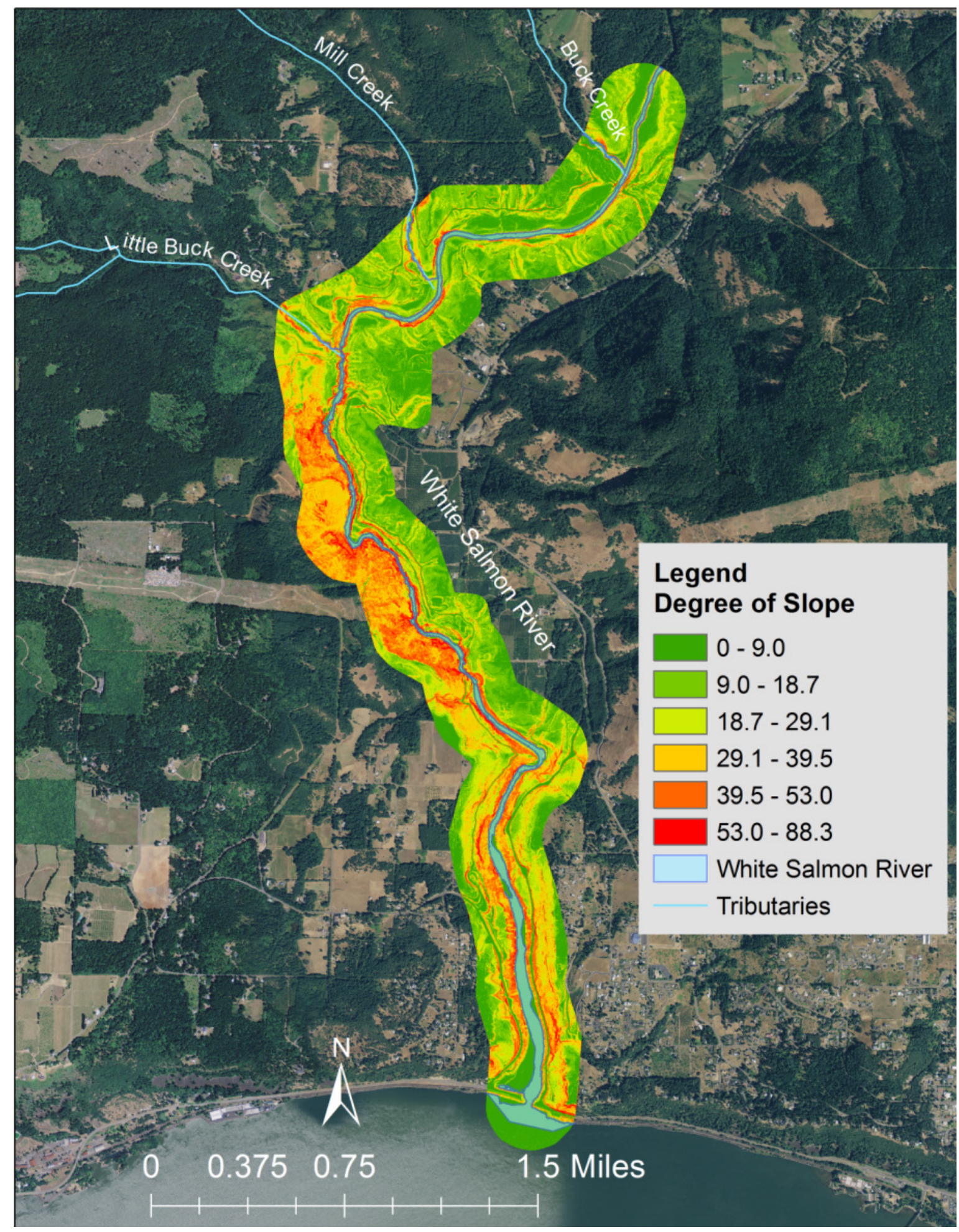

Figure 4. Map showing near-shore bank slope in degrees in the lower White Salmon River, Washington. 


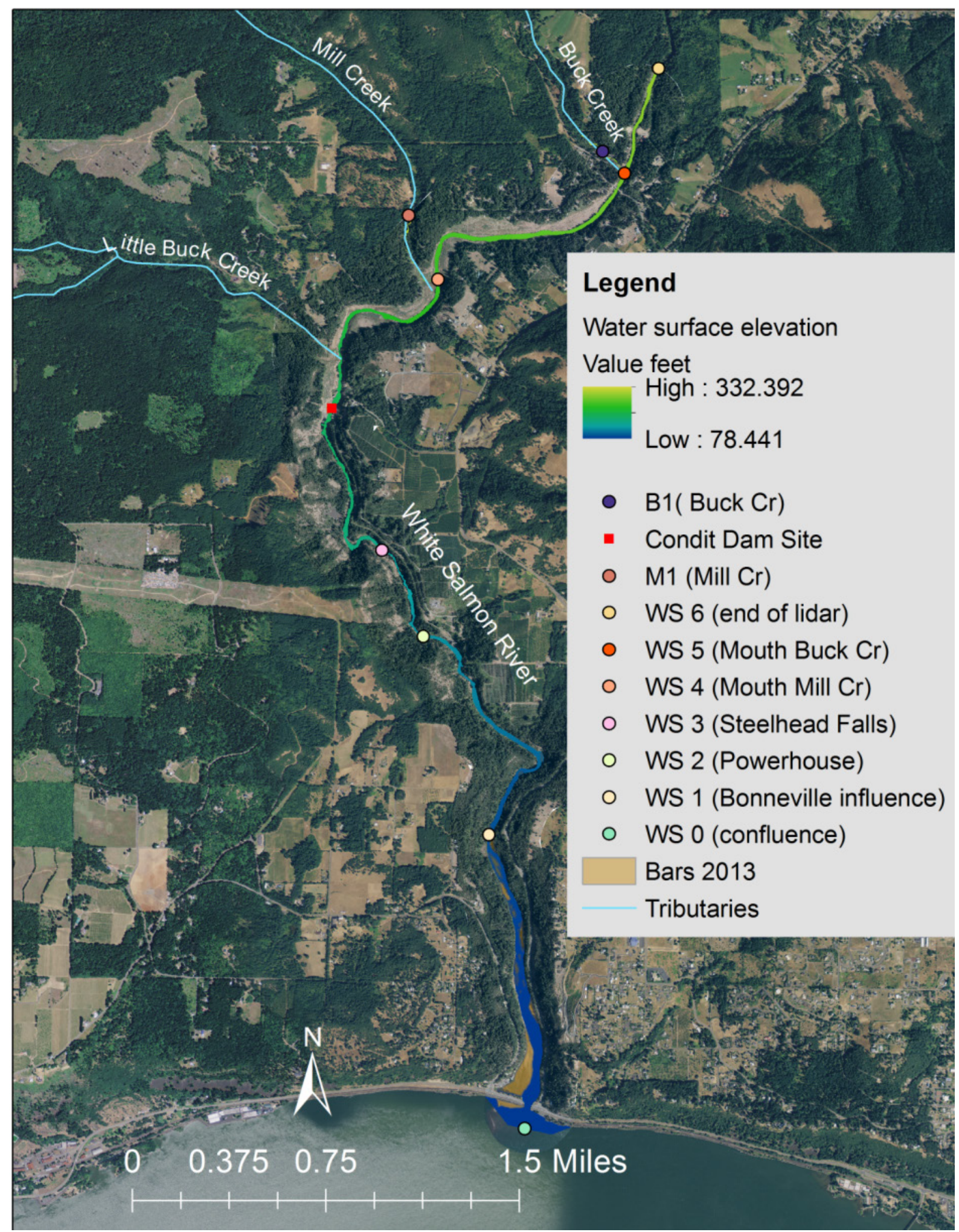

Figure 5. Map showing water-surface elevation and study area reach breaks in the lower White Salmon River, Washington. 
The USGS previously collected detailed habitat information from the mouth of the White Salmon River to $1 \mathrm{mi}$ upstream both pre- and post-dam removal (J. Hatten, U.S. Geological Survey, written commun., 2014). This information was incorporated into the GIS and includes bathymetric surveys, substrate information, and a two-dimensional river hydrodynamic model. This information was used to compare the movement of gravel bar beds from 2012 to 2013 and to illustrate the dynamic nature of the river as it is finding equilibrium after Condit Dam removal (fig. 6). One general conclusion of this report was that there was improved salmon habitat in the lowest river mile after dam removal due to increased gravel recruitment, favorable velocities, and depths for spawning (J. Hatten, U.S. Geological Survey, written commun., 2014). Although, it was further noted that the lowest river mile still has some channel instability, and the potential for gravel bars to change if and when a larger flood event occurs. Additional existing habitat data were referenced where possible from past survey work, reports, and field observations (Northwest Power and Conservation Council, 2004; Allen and Connolly, 2005; Allen and Connolly, 2011; Plummer and Zuckerman, 2012; JR Merit Industrial Contractors, 2013; Riverbend Engineering LLC and JR Merit Industrial Contractors, 2013).

\section{Fish Use}

The USGS collected outmigration data on the lower White Salmon River fish species composition prior to Condit Dam removal. They used a rotary screw trap at river km 1.5 (RM 0.93) from March to June in 2006 through 2009 (Allen and Connolly, 2011), and drew the following conclusions:

- Fall Chinook salmon were captured in the greatest numbers $(n=18,640)$ compared to other fish species, and were composed of two stocks - tule and upriver bright. Almost all captured fall Chinook salmon were age- 0 , with only 16 ( 0.09 percent) being age- 1 or older.

- Tule fall Chinook salmon, the native stock, generally out-migrated from mid-March through early April. The tule stock was the more abundant fall Chinook salmon subspecies, comprising 85 percent of those captured in the trap.

- Upriver bright fall Chinook salmon comprised 15 percent of the Chinook salmon catch and generally out-migrated from late May to early June. However, during WDFW spawning surveys from 2006 through 2013, the upriver bright fall Chinook were consistently more abundant than tule fall Chinook salmon.

- Coho salmon and steelhead trout were captured by the rotary screw trap in all years. Coho salmon were captured in low numbers $(n=661)$ and 69 percent were age- 0 fish. Steelhead were slightly more abundant $(n=679)$ than coho salmon and 84 percent were age- 1 or older fish.

The USGS also electrofished when water levels in the White Salmon River declined in late summer, along the river margins in 2006-09 at three sites (approximately RM 0.9, 1.4, and 2.6). Age-0 steelhead were the most abundant fish captured $(n=565,62$ percent), followed by age- 0 coho salmon $(\mathrm{n}=222,24$ percent). There were no age- 1 and few age-0 Chinook salmon collected while electrofishing $(\mathrm{n}=40,4$ percent $)$. The only age- 1 salmonids captured while electrofishing were steelhead $(\mathrm{n}=84,9$ percent; Allen and Connolly, 2011). This composition likely has changed since the removal of Condit Dam; however, a more recent survey for juvenile distribution and composition has not been done and this is considered a data gap for salmonid use in the White Salmon River. This past work provides evidence of early salmonid life history stages rearing in and outmigrating from the lower river (Allen and Connolly, 2011). 


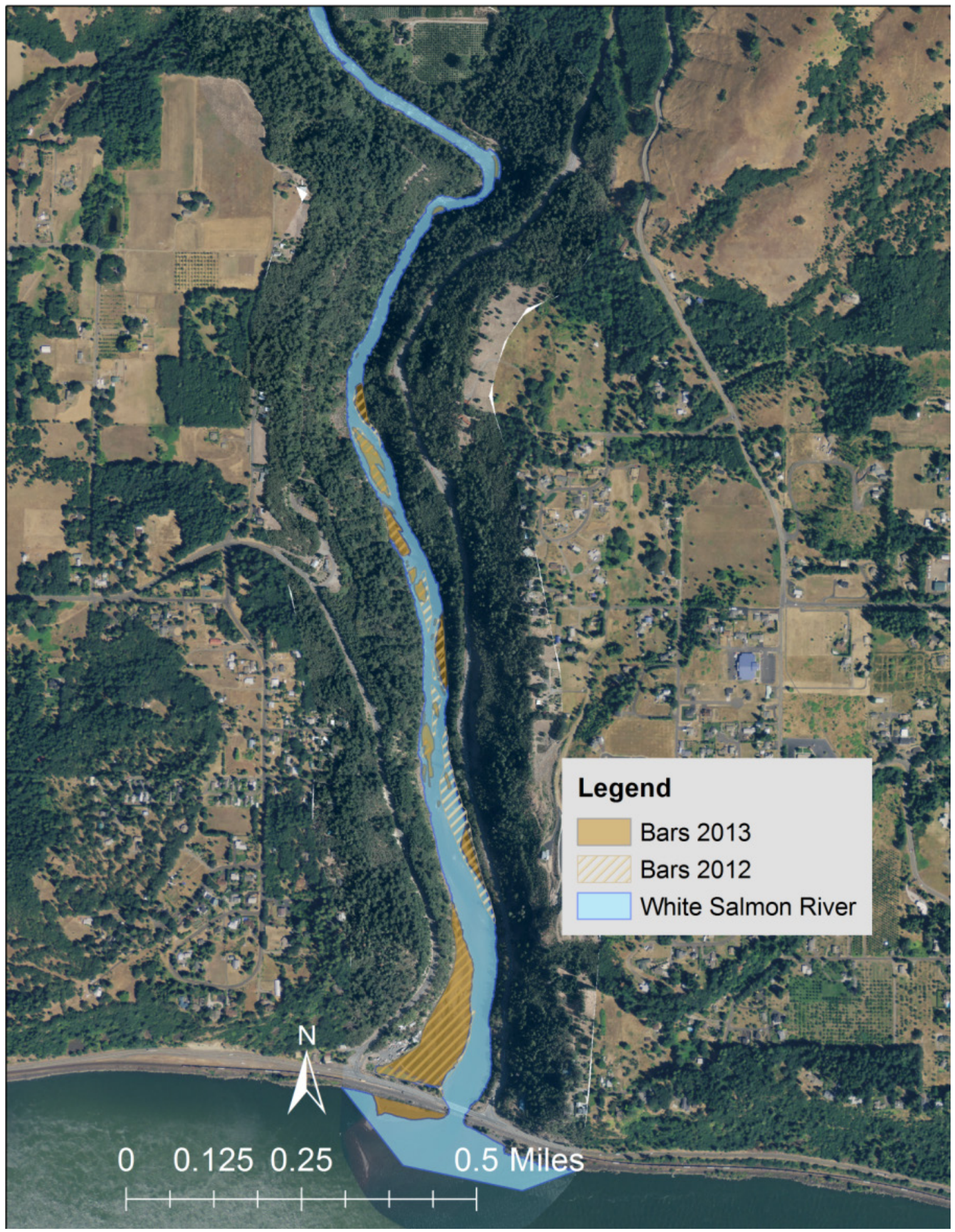

Figure 6. Map showing change from 2012 to 2013 in gravel bar location and size in the first river mile of the White Salmon River, Washington. 
After dam removal, spawning surveys have been conducted by USFWS in 2012 and WDFW in 2013 and 2014 during autumn. For a complete description of survey methodology for the 2012 survey, see Engle and others (2013). During weekly surveys from September 20 to November 15, 2012, three main reaches were surveyed downstream of Husum Falls to the confluence with the Columbia River. Not all reaches were surveyed every week. Redd surveys were conducted from inflatable rafts and all redd observations were recorded and marked on maps for digitizing and enumeration into a GIS. From the 2012 effort, the USGS was able to obtain GPS points of redd locations and incorporate these into a GIS (figs. 7 and 8).

The 2013 and 2014 survey methodology was unpublished at this time, but methods are briefly described here (Jeremy Wilson, Washington Department of Fish and Wildlife, written commun., 2015). In addition to spawning surveys, the WDFW has implemented a more comprehensive Viable Salmonid Population (VSP) parameter monitoring program for Chinook salmon populations downstream of Bonneville Dam. The monitoring is focused on estimating adult abundance, spatial distribution, diversity and productivity with the goal of meeting National Oceanic and Atmospheric Administration's guidance criteria for precision and accuracy (McElhany and others, 2000; Crawford and Rumsey, 2011). Spawning surveys were conducted weekly from early August to mid-December from Husum Falls (RM 7.8) to the mouth, with one supplemental survey conducted from BZ Falls (RM 12.3) to Husum Falls during peak spawning times. During the 2013 survey, GPS points were collected on Spring Chinook salmon redds primarily, as they were in a lower abundance than the tule fall Chinook and the bright fall Chinook salmon runs. These were collected from August 19 to November 26 during weekly survey efforts (figs. 7 and 8). Individual GPS points were not collected weekly for the fall Chinook and bright salmon runs due to the higher abundance of spawners and redds and the high occurrence of superimposition in the lowest river miles. However, counts and location descriptions were recorded as best as possible, realizing the potential for underestimation of individual redds during this period.

Steelhead spawning surveys have been conducted by the Yakama Nation in the tributaries but not within the mainstem White Salmon study area. The lack of information on mainstem spawning potential for steelhead and coho salmon are considered data gaps for this area. However, we do know that steelhead/rainbow trout redds have been observed in tributaries upstream of the former reservoir, primarily in Buck and Rattlesnake Creeks (Joe Zendt, Yakama Nations Fisheries, written commun., 2015). There is also evidence of steelhead occurring up to BZ Falls and even Big Brother Falls (RM 15.5; Joe Zendt, Yakama Nations Fisheries, written commun., 2015), both upstream of Husum Falls, indicating this is not a complete passage barrier for steelhead. 


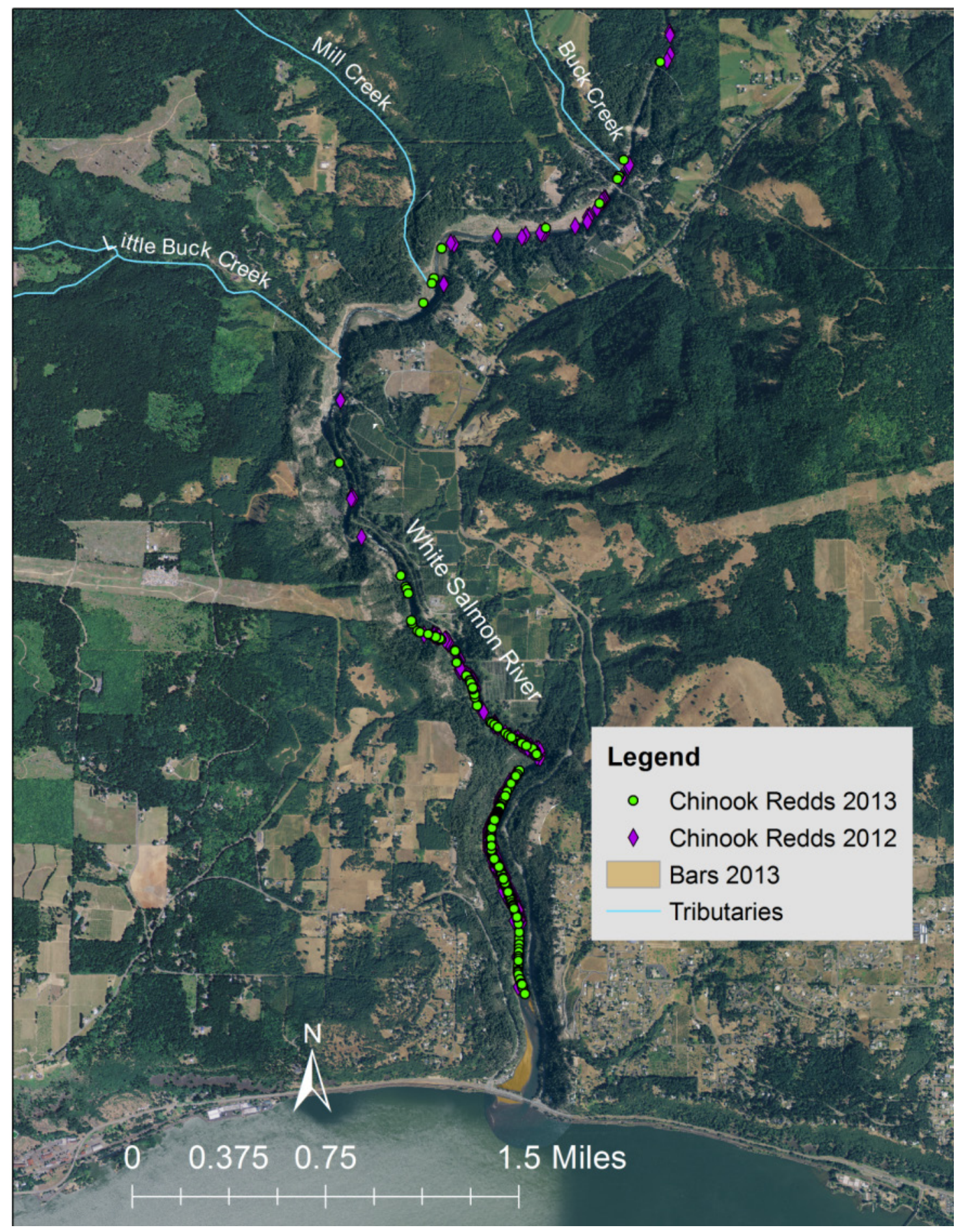

Figure 7. Map showing Chinook salmon redd survey results from U.S. Fish and Wildlife Service surveys during autumn 2012 and from Washington Department of Fish and Wildlife surveys of Chinook salmon redds in 2013 in the lower White Salmon River, Washington. 


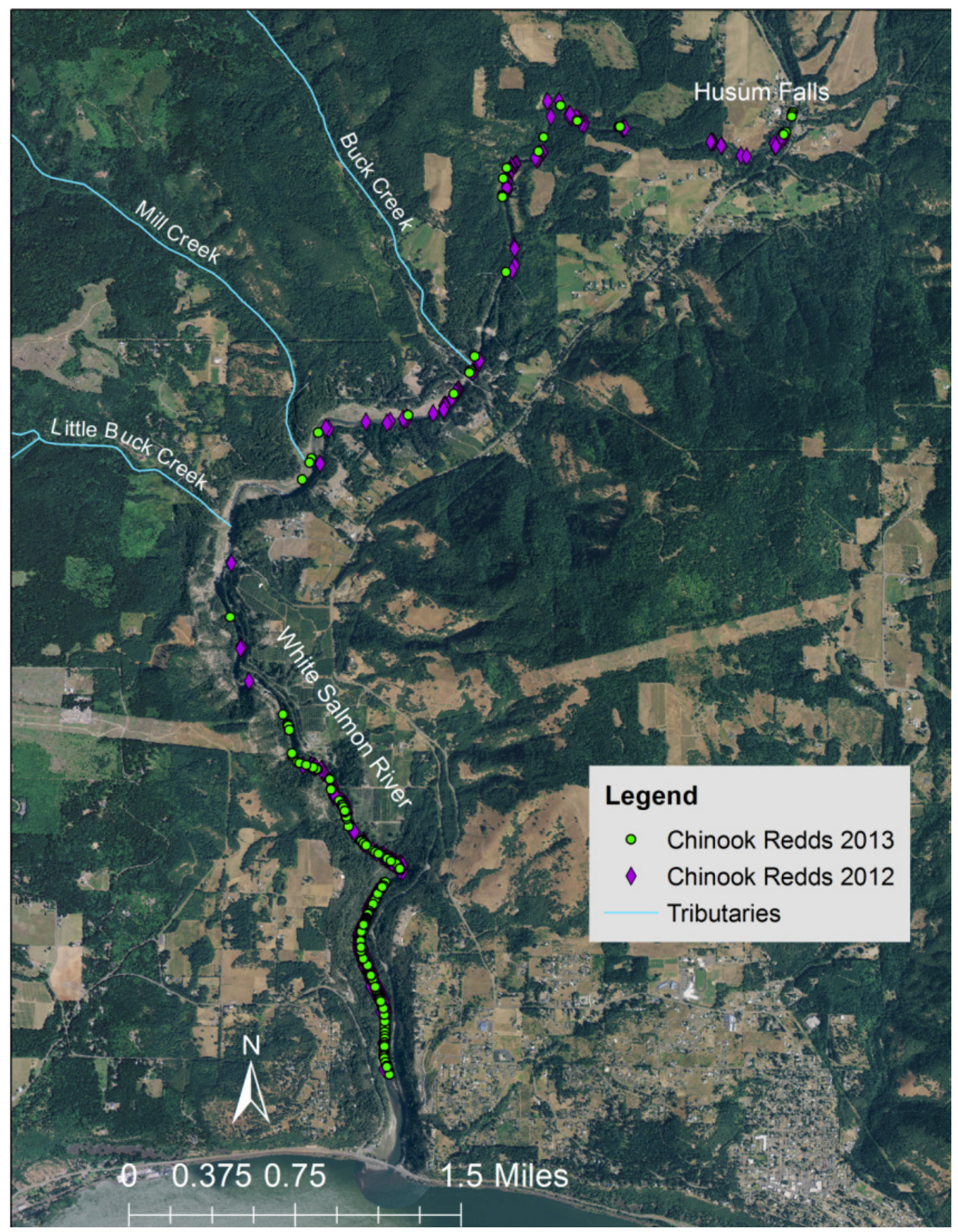

Figure 8. Map showing Chinook salmon redd survey results from U.S. Fish and Wildlife Service surveys during autumn 2012 and from Washington Department of Fish and Wildlife surveys of Chinook salmon redds in 2013 in the lower White Salmon River, Washington. Includes the study area (confluence up to Buck Creek) and upstream to Husum Falls. 


\section{Fish Habitat Criteria by Life History Stage}

Habitat preferences of the salmonid species of interest and life history stages have been well documented in the literature (Groot and Margolis, 1991; Inter-Fluve, 2013, appendix D). Generally, prior to spawning, adult salmonids prefer to hold in deep pools with cover (for example, LWD, boulders, shadows, depth) near spawning areas, with a variety of suitable substrate types, and with temperatures ranging from 3.3 to $19.4{ }^{\circ} \mathrm{C}$ (Bell, 1986). Typical Chinook and coho salmon spawning habitat occurs in water depths greater than 7-9.5 in., with velocities between 11 and 36 in/s, with substrate in the size range of 0.5 to $4 \mathrm{in}$. (Thompson, 1972), and fines less than 20 percent. The water temperature ranges from 4.4 to $14.0^{\circ} \mathrm{C}$ and is not limiting in the White Salmon River, nor is dissolved oxygen a limiting factor (Allen and Connolly, 2005). These conditions are similar to spawning habitat needed for steelhead, with the exception of a slightly narrower velocity range of 15-36 in/s, broader substrate range of $0.2-4 \mathrm{in}$, and a narrower temperature range of $4-10^{\circ} \mathrm{C}($ Bell, 1986). Incubation temperatures typically fall in the same range as the spawning criteria as well as the other habitat conditions, including limited scour or high flow events during this period. Habitat preferences of rearing and out-migrating juvenile salmonids include lower velocities, $0-15$ in/s, shallower depths about 6 in., smaller substrate (0.2-0.6 in.; Garland and others, 2002), cobble embeddedness less than 20 percent (National Marine Fisheries Service, 2013), and access to cover. Juveniles are often found along stream margins in the slower moving water, shallower depths, with adequate cover (for example, vegetation, woody debris).

\section{Reach Ranking Methodology}

Individual reaches were ranked for conservation planning purposes either in a descriptive manner or numerically based on fish-use and (or) habitat information (that is, percentage of slope) as available for individual life-history stages. Because of the lack of information about current fish use in the White Salmon River for the various salmonid species and many of the life history stages (that is, rearing, migration), ranking of these were applied in a more descriptive manner based on available habitat and fish-use data and fish life-stage preference as described in the habitat criteria section. The most complete datasets we have for fish use after fish passage was restored are the 2012 and 2013 Chinook salmon redd surveys. Therefore, the spawning life-history stage is the only life-history stage that was ranked numerically. The number of redds/mile was estimated from the spawning survey observations for each reach, and the reach with the highest redd density was ranked as a one, the next highest ranked a two, and so on. The 2013 redd survey data summarized here represent the general patterns of redd distributions observed and are consistent with the 2012 observations and preliminary results from the 2014 redd survey (Jeremy Wilson, Washington Department of Fish and Wildlife, written commun., 2015).

\section{Results}

\section{Habitat Description}

The mainstem lower White Salmon River including the former Northwestern Lake area up to the confluence with Buck Creek was mostly confined through a basalt canyon or by steep embankments (figs. 3 and 4; Haring, 2003). There was little habitat complexity with floodplain interaction, LWD, backwaters, eddies, or sandbars throughout the entire study area (JR Merit Industrial Contractors, 2013). The lowest river mile was an exception because of numerous gravel bars that have formed post-dam breach and continue to change with high water events (fig. 6). The mainstem instream habitat 
complexity was made up of overhanging bedrock shelves, bedrock pools, boulders, and sparse LWD, and was considered moderate (Haring, 2003; Plummer and Zuckerman, 2012). Bedrock cliffs line the river throughout most of the lower White Salmon River downstream of the former site of Condit Dam. In some areas, bedrock creates waterfalls, such as Steelhead Falls at RM 2.6. This falls is not considered a fish passage barrier for salmonids. As part of decommissioning efforts, seven Engineered Log Jams (ELJs) were constructed within the former reservoir reach (JR Merit Industrial Contractors, 2013). We georeferenced and incorporated into the GIS 11 natural and man-made LWD jams or ELJs along the shore margins in the study area. This could be used as a baseline reference for future changes in the fish habitat and continued monitoring efforts. During monitoring efforts in 2013, no large woody debris obstructions to boating or fish passage were observed that would acquire active management or removal (JR Merit Industrial Contractors, 2013). The ELJs have remained in place and were conducive to the creation of downstream eddies, bank stabilization, and fish holding areas.

The general habitat types within the study reach are largely riffles, runs, with some cascades and pools (Plummer and Zuckerman, 2012). On average, the gradient of the water-surface elevation ranges from 0.2 to 1.2 percent in the individual reaches of the lower 6 river miles (table 2). Upstream of the former Northwestern Lake, river gradients generally range between 2 and 11 percent (Haring, 2003). Prior to the release of sediment behind the dam, the water depth of the lowermost mile of the White Salmon River was influenced by the backwater effect of the Columbia River's Bonneville Pool, which was impounded by Bonneville Dam, and the water in the lowermost $0.5 \mathrm{mi}$ was more than $9 \mathrm{~m}$ deep (J. Hatten, U.S. Geological Survey, written commun., 2014). The outflow of silt, sand, and gravel from dam breaching aggraded the lower river by about $1.5 \mathrm{~m}$ (Wilcox and others, 2014). The sediment filled pools throughout the lower river, created gravel bars, and created a small delta at the Columbia River confluence (fig. 6). In 2014, the lowermost $0.3 \mathrm{mi}$ of the White Salmon River continued to be influenced by Bonneville Pool and was approximately $6 \mathrm{ft}$ deep (J. Hatten, U.S. Geological Survey, written commun., 2014). Throughout the study area, suitable habitat was available for many of the salmonid life history stages habitat criteria.

The Underwood Conservation District performed vegetation surveys as part of their Anadromous Fish Passage Inventory assessment from May through October in 2009 and 2010 (Plummer and Zuckerman, 2012). They noted that vegetation composition shifts throughout the $16.9 \mathrm{mi}$ of potentially anadromous habitat in the mainstem of the White Salmon River. Throughout the entire river corridor, mature trees shaded the river with a canopy cover ranging from 5 to 35 percent. The relatively low canopy cover was due to steep bedrock banks and narrow canopied tree species that line the banks. Downstream of the former Condit Dam site, there were rocky slopes and cliffs dominated by Oregon white oak (Quercus garryana), as well as sections consisting mainly of Douglas-fir, big leaf maple, red alder, and some Western red cedar; with vine maple, hazelnut, and Oregon ash dominant in the subcanopy (Plummer and Zuckerman, 2012). Upstream of the former dam site, along the former reservoir shorelines, the riparian habitat was dense with Douglas-fir (Pseudotsuga menziesii), Western red cedar (Thuja plicata), black cottonwood (Populus trichocarpa), red alder (Alnus rubra), big leaf maple (Acer macrophyllum), vine maple (Acer cicinatum), ocean spray (Holodiscus discolor), willows (Salicaceae), horsetail (Equisetum), and Douglas spirea (Spiraea douglasii). In 2014, re-vegetation projects lead by PacifiCorp and Yakama Nation Fisheries were underway in the area of the former Northwestern Lake in the newly exposed sediment areas. As newly planted vegetation becomes established near the new river channel, there is the potential for increased shade cover, nutrient inputs, bank stability, and potential sources for large woody debris. In 2014, the former Northwestern Lake reservoir area was lacking a properly functioning riparian corridor. 


\section{Fish-Use/Redd Surveys}

During 2012, the USFWS conducted limited redd surveys due to dam removal operations, adverse weather, and difficult river conditions. The reach from RM 7.6 to RM 0.0 was surveyed only three times. The results of the Chinook salmon redd surveys in 2012 indicated that the density of use was highest in lowermost 2 river miles (fig. 7). However, redds were observed throughout the study area, including in the former reservoir, just upstream of the Northwestern Lake Bridge, and upstream of the study area to Husum Falls (fig. 8; Engle and others, 2013). This indicated that the entire lower 6 river miles were used as a migration corridor for adults to access upper spawning areas and the area was used by juveniles as they reared and out-migrated. The distribution of spawning fall Chinook salmon adults in 2012 suggested the lower White Salmon River was suitable for spawning, including new spawning habitat in the former reservoir.

Results from the more extensive 2013 Chinook salmon redd surveys, conducted by WDFW, were consistent with the results from the 2012 redd surveys (fig. 7). The highest numbers of redds were from RM 2.1 downstream to a couple hundred yards upstream of the confluence with the Columbia River. As in the previous year, a handful of fall Chinook salmon were observed spawning upstream of the former Condit Dam site (RM 3.27), including some near the Buck Creek confluence (RM 4.90), the "castle" house (approximately RM 5.5), and up to the area just downstream of Rattlesnake rapid (just downstream of Husum Falls, approximately RM 7.6; fig. 8). About 42 percent of the spawning spring Chinook salmon were observed upstream of the former Condit Dam site (Jeremy Wilson, Washington Department Fish and Wildlife, written commun., 2014). Most of the spring Chinook salmon redds that were upstream of the former Condit Dam site were 90-180 m downstream of the Rattlesnake Creek confluence, with a few redds near the "castle" house. The bulk of the fall Chinook spawning occurred downstream of Steelhead Falls (RM 2.6), with the highest concentration from the USFWS raceways (RM 1.3) down to the mouth (Jeremy Wilson, Washington Department of Fish and Wildlife, written commun., 2014).

During 2014, WDFW continued to do spawning surveys, with preliminary results summarized here. For the spring Chinook salmon, spawner abundance estimates were two to three times what was observed in 2013 (Jeremy Wilson, Washington Department of Fish and Wildlife, written commun., 2014). The tule fall Chinook salmon abundance estimates also were higher than those observed during 2013. There was an increased use of the habitat upstream of the former Condit Dam site by the spring Chinook salmon, while the tule fall Chinook salmon were primarily observed using the reaches downstream of Steelhead Falls. Spring Chinook salmon also were observed in Spring Creek in 2014, which is a tributary upstream of the former reservoir at RM 6.6 (Greg Morris, Yakama Nations Fisheries, written commun., 2014).

Information about the timing of adult fish spawning can be summarized from WDFW's 2013 unpublished results, indicating Chinook salmon spawning from September until early December (Jeremy Wilson, Washington Department of Fish and Wildlife, written commun., 2014). This spawning activity is focused in the lowest 2 river miles. Spring Chinook salmon likely hold in deeper pools in the White Salmon River beginning in May, and fall Chinook begin staging for spawning in late August. In 2006 through 2009 at RM 1, bi-modal peak outmigration periods of fall Chinook salmon fry occurred during mid-March to early April and again in late May to early June (Allen and Connolly, 2011). Although this study occurred prior to Condit Dam removal, this likely continues to be the out-migration timing post=-removal. This should be noted as a data gap and updated monitoring efforts are warranted post-Condit Dam removal. 


\section{Reach Ranking}

Critical spawning habitat areas were identified based on the spatial information provided from redd locations and the reaches in the study area were given a rank, which identified the lower ranked numbers as areas that had the highest Chinook salmon spawning density (table 3 ). In the process of developing conservation planning, the lowest $2 \mathrm{mi}$ had the highest density for spawning and would be given the highest priority for protection. Without additional salmonid use information since removal of Condit Dam, we are left to rely on historical data and habitat suitability assumptions to rank reaches for the other species and life history stages. With the assumption that juvenile salmonids will likely be rearing near and downstream of the reaches with the highest densities of redds, the lowest 2 mi would also rank highest for juvenile Chinook salmon rearing. Juvenile rearing would also likely be higher in the reaches with lower gradients, such as reaches 1,2,5, and 6 (table 2), because the preferred rearing velocities of most salmonids are lower than the preferred spawning velocities. Juveniles would use the shallower habitats with suitable cover along the river shoreline margins within these reaches.

Table 3. Reach prioritization for the White Salmon River based on redd data from 2012 and 2013.

[Prioritization ranking was assigned a 1 for the highest density of redds from surveys by U.S. Fish and Wildlife Service in 2012 and Washington Department of Fish and Wildlife in 2013, and was sequential after that. For 2012, ranking was based on observed redds from September to November. The 2013 ranking used data from Chinook salmon redd surveys in early August to mid-December]

\begin{tabular}{clccc}
\hline $\begin{array}{c}\text { Reach } \\
\text { name } \\
\text { (see } \\
\text { fig. 5) }\end{array}$ & \multicolumn{1}{c}{ Description } & White Salmon & \multicolumn{2}{c}{ Prioritization ranking } \\
\cline { 4 - 5 } & & River miles & Redd 2012 & Redd 2013 \\
\hline WS1 & Confluence to end of Bonneville influence & $0-1.1$ & 2 & 1 \\
WS2 & End of Bonneville influence to powerhouse & $1.1-2.2$ & 1 & 2 \\
WS3 & Powerhouse to Steelhead Falls & $2.2-2.6$ & 6 & 3 \\
WS4 & Steelhead Falls to mouth of Mill Creek & $2.6-4.2$ & 5 & 4 \\
WS5 & Mouth of Mill Creek to mouth of Buck Creek & $4.2-5.2$ & 3 & 4 \\
WS6 & Mouth of Buck Creek to end of study area (lidar dataset) & $5.2-5.7$ & 4 & 4 \\
\hline
\end{tabular}




\section{Discussion}

The restoration of fish passage in the White Salmon River has provided access to as much as 33 mi of habitat for anadromous species (Washington State Department of Ecology, 2007; National Marine Fisheries Service, 2013). The management plan for the first 5 years was to allow for natural recolonization of salmonids to this river (National Marine Fisheries Service, 2013). Natural resource managers are continuing to collect data of fish use through spawner and carcass surveys in 2015. This region is in the public eye for recreational use, business use (rafting companies), private landowner access, public access, and the potential future changes to land use in the study area. The high level of interest in this area was evident at public meetings (May 17 and November 15, 2014) held to discuss fish habitat assessment and land development suitability for the study area. The information presented here is a continuation of the initial steps since removal of Condit Dam towards understanding salmon use (Engle and others, 2013) and habitat conditions in the former reservoir down to the confluence with the Columbia River.

The lower White Salmon River continues to be used by salmon for spawning and rearing downstream of the former Condit Dam site and salmon and steelhead are using the newly accessible habitat upstream of the dam site as well. The general trend for the last 2 years of spawning surveys was increasing numbers of returning Chinook salmon and increasing redd locations (Jeremy Wilson, Washington Department of Fish and Wildlife, written commun., 2015). The highest numbers of redd locations were in the lowest $2 \mathrm{mi}$ of the river. Since dam removal, the habitat in this area has become even more suitable for spawning, with an overall decrease in pool depth from about 29 to $6 \mathrm{ft}$, increased gravel recruitment suitable for spawning habitat, and a decrease in the percentage of fine substrates (J. Hatten, U.S. Geological Survey, written commun., 2015). Furthermore, this section of river has gained channel complexity with newly formed gravel bars; however, channel instability is still present because the lower river continues to be in a state of flux. This study focused on the lower 6 river miles; however, observations of redd locations upstream of the study area are evidence of range expansion of spawning habitat and fish use where river velocities, depths, and substrate are suitable.

This habitat and fish-use assessment provides support for the success of the explosive (often referred to as a "blow-and-go" approach) Condit Dam breaching and natural recolonization management approach for salmonid populations in the White Salmon River. At the time of breaching, the 125-ft-tall Condit Dam was the largest in the nation to be breached in a single explosive event. Since then, Glines Canyon Dam (210 ft tall) on the Elwha River, Washington, is now the tallest to be removed. The removal of Glines Canyon Dam was staged over a multiyear process considered a notch-it-down approach to slowly release the sediment accumulated behind the dam (Warrick and others, 2012). Although the initial pulses of sediment and reservoir water from the Condit Dam breach was expected to temporarily scour and eliminate any redds within the lower White Salmon River (Engle and others, 2013), natural recolonization has been occurring since the dam removal. Salmonids were observed spawning in the White Salmon River both upstream and downstream of the former Condit Dam site the same year the dam removal was completed (Engle and others, 2013). Furthermore, spawning has been observed each year a survey has been performed since removal (Jeremy Wilson, Washington 
Department of Fish and Wildlife, written commun., 2015). The mitigation efforts by USFWS and others (Engel and others, 2013) to translocate Chinook Salmon to spawn upstream of Condit Dam prior to the breach in 2011 has likely added to salmon returns. Genetic analysis of tissues from carcass surveys from the 2014 and 2015 survey efforts could confirm this. Although, many factors should be considered in dam removal approaches (that is, sediment composition; Wilcox and others, 2014) and ecological and biological impacts, the speed that salmonids returned to the White Salmon River and found habitat suitable for spawning and rearing can provide a positive example of the blow-and-go approach for other potential dam removals throughout the nation.

A major limitation of this assessment was that no new habitat or fish surveys were done as part of this study; thus, this work focused on summarizing existing information with an emphasis on the available spatial datasets. New habitat surveys should be conducted to monitor changes in substrate (that is, gravel recruitment, fines distribution), pool numbers and depths, riparian cover, etc. Also, a watershed approach that considers the information of fish use upstream of the former reservoir and within the tributaries may more fully represent fish use in the lower river. There are four main tributaries that are likely accessible to anadromous fish; however, three of these also have waterfalls 1.4-3 RM upstream of their mouths that are seasonal or complete barriers, depending on the fish species (Allen, 2012; Plummer and Zuckerman, 2012). These tributaries are Rattlesnake Creek (entering the White Salmon at RM 7.4), Spring Creek (RM 6.6), Buck Creek (RM 5), and Mill Creek (RM 4; Allen, 2012). In order to better understand the potential for the White Salmon River to support salmonid populations, there needs to be a better understanding of the full habitat being used, the species using them, and the productivity within these systems, including the tributaries. Data gaps currently exist for recent (post-dam removal) juvenile salmonid composition, rearing, and out-migration timing. More comprehensive spawning and (or) presence absence surveys including steelhead, coho salmon, lamprey, bull trout, and other species are needed. Pacific and brook lamprey occupied the White Salmon River downstream of Condit Dam (Jolley and others, 2012). Lamprey are expected to recolonize the White Salmon River after dam removal (Allen, 2012), but their status after removal has not been assessed. Other than the fall Chinook salmon, the stocks of salmonids that are recolonizing the river are unknown; thus, more comprehensive surveys including a genetic component would be beneficial. Additionally, surveys targeting invasive species within the White Salmon River would be prudent for early detection and potential control of unwanted species. Invasive plants have already been documented within the lower White Salmon River corridor (Plummer and Zuckerman, 2012), and restoration projects targeted at removal efforts would be prudent. Generally, the river ecosystems are properly functioning and the habitat conditions are very suitable for salmonids. Water quality (temperature, dissolved oxygen) and quantity are not limiting in the mainstem White Salmon River. Also, fish habitat conditions are likely to improve as ecosystem processes come to an equilibrium and are enhanced with improvements to the riparian corridor aided by the re-vegetation projects underway and some of the LWD/ELJ placements.

There are also potential threats to the salmon habitat from future development, such as roads, buildings, septic tanks, and increased surface-water or groundwater withdrawals (Haring, 2003). Other potential threats are increased fish harassment, redd disturbance (potential damaging of eggs), riparian erosion, vegetation clearing, and trash from an increase in recreational use in the lower reaches, now that new access was gained by a continuous, free-flowing stretch of river allowing for boaters, rafters, and fishermen to float to the mouth of the river. This connectivity can also allow for potential increase in likelihood of invasive species establishment throughout the river corridor. The region will be well served by conservation planning efforts and strategies that address conservation alternatives for protection of critical salmon habitat while addressing community issues and uses. 


\section{References Cited}

Allen, M.B., 2012, An annotated bibliography for lamprey habitat in the White Salmon River, Washington: U.S. Geological Survey Open-File Report 2012-1086, 28 p.

Allen, M.B., and Connolly, P.J., 2011, Current use and productivity of fish in the lower White Salmon River, Washington, prior to the removal of Condit Dam: U.S. Geological Survey Open-File Report 2011-1087, 32 p.

Allen, B., and Connolly, P.J., 2005, Assessment of the White Salmon watershed using the ecosystem diagnosis and treatment model: U.S. Geological Survey, Final Report prepared for Yakima Nation Fisheries Department, Agreement No. BGC045052.

Bell, M.C., 1986, Fisheries Handbook of engineering requirements and biological criteria: Portland, Oregon, U.S. Army Corps of Engineers.

Columbia River Gorge Commission, 1991, Columbia River Gorge National Scenic Area-Management plan: Columbia River Gorge Commission, variously paged. [Also available at http://www.gorgecommission.org/managementplan.cfm.]

Cowan, B., 1999, WRIA 29 Salmonid Habitat Limiting Factors Analysis Report: Olympia, Washington, Washington Conservation Commission, 98 p.

Crawford, B.A., and Rumsey, S.M., 2011, Guidance for monitoring recovery of Pacific Northwest salmon and steelhead listed under the federal endangered species act: Portland, Oregon, National Oceanic and Atmospheric Administration, National Marine Fisheries Service, Northwest Region.

Engle, R., Skalicky, J., and Poirier, J., 2013, Translocation of lower Columbia River fall Chinook Salmon (Oncorhynchus tshawytscha) in the year of Condit Dam removal and year one post-removal assessments. 2011 and 2012 Report: U.S. Fish and Wildlife Service, Columbia River Fisheries Program Office, Vancouver, Washington, $47 \mathrm{p}$.

Federal Energy Regulatory Commission, 1996, Final environmental impact statement, Condit Hydroelectric Project, Washington-FERC Project No. 2342-005: Washington , D.C., Federal Energy Regulatory Commission, accessed November 2014, at http://www.pacificorp.com/content/dam/pacificorp/doc/Energy_Sources/Hydro/Hydro_Licensing/Con dit/Final_Environmental_Impact_Statement_FEIS_1996.pdf.

Garland, R.D., Tiffan, K.F., Rondorf, D.W., and Clark, L.O., 2002, Comparison of subyearling fall Chinook Salmon's use of riprap revetments and unaltered habitats in Lake Wallula of the Columbia River: North American Journal of Fisheries Management, v. 22, p. 1,283-1,289.

Greenworks, Kleinfelder, and JR Merit Industrial Contractors, 2011, Revegetation and wetlands management plan: Prepared for PacifiCorp, Condit Hydroelectric Project Decommissioning FERC Project No. 2342, 48 p. Available:

http://www.pacificorp.com/content/dam/pacificorp/doc/Energy_Sources/Hydro/Hydro_Licensing/Con dit/20110315RevegWetlandsMgmtPlan.pdf (April 2015).

Groot, C., and Margolis, L., 1991, Pacific salmon life histories: Vancouver, British Columbia, University of British Columbia Press, ISBN 0-7748-0359-2.

Haring, D., 2003, Addendum to wind/white salmon WRIA 29, salmonid habitat limiting factor analysis (originally issued July 1999)_White Salmon River Watershed: Washington Conservation Commission.

Interior Columbia Technical Recovery Team, 2008, Current status reviews-Interior Columbia basin salmon and steelhead ESUs, volume III: MCR Steelhead DPS. May 2008. Draft.

Inter-Fluve, 2013, Literature review of mainstem Columbia River anadromous salmonid habitat and restoration potential between Bonneville Dam and the Yakima River Confluence: Inter-Fluve, Prepared for Mid-Columbia Fisheries Enhancement Group, White Salmon, Washington, 44 p. 
Inter-Fluve, Kleinfelder, and JR Merit Industrial Contractors, 2011, Sediment assessment, stabilization, and management plan: Inter-Fluve, Kleinfelder, JR Merit Industrial Contractors, Prepared for PacifiCorp Energy, Condit Hydroelectric Project Decommissioning FERC Project No.2342, 30 p., accessed April 2015, at http://www.pacificorp.com/content/dam/pacificorp/doc/Energy_Sources/Hydro/Hydro_Licensing/Con dit/20110315SedimentMgmt.pdf .

Jolley, J.C., Silver, G.S., and Whitesel, T.A., 2012, Occurrence, detection, and habitat use of larval lamprey in the White Salmon River Basin pre-Condit Dam removal-2011 annual report: U.S. Fish and Wildlife Service, Columbia River Fisheries Program Office, Vancouver, Washington, 21 p.

JR Merit Industrial Contractors, 2013, Woody debris annual monitoring report 2013: Portland, Oregon, JR Merit Industrial Contractors, Prepared for PacifiCorp Energy, 12 p. Available:, accessed April 2015, at http://www.pacificorp.com/content/dam/pacificorp/doc/Energy_Sources/Hydro/Hydro_Licensing/Con dit/woody_debris_2013.pdf.

Lane \& Lane Associates, 1981, White Salmon River Indian fisheries and Condit Dam: Portland, Oregon, Lane and Lane Associates with Douglas Nash, Prepared for the Bureau of Indian Affairs.

McElhany, P., Ruckelshaus, M.H., Ford, M.J., Wainright, T.C., and Bjorkstedt, E.P., 2000, Viable salmonid populations and the recovery of evolutionarily significant units: National Oceanic and Atmospheric Administration, NOAA Technical Memorandum NMFS-NWFSC-42.

Myers, J., Busack, C., Rawding, D., Marshall, A.R., Teel, D.J., Van Doornik, D.M., and Maher, M.T., 2006, Historical population structure of Pacific salmonids in the Willamette River and lower Columbia River basins: National Oceanic and Atmospheric Administration Technical Memorandum NMFS-NWFSC-73.

National Marine Fisheries Service, 2013, ESA Recovery Plan for the White Salmon River Watershed: National Marine Fisheries Service Northwest Region, 186 p.

Northwest Power and Conservation Council, 2004, Draft white salmon subbasin plan: Portland, Oregon, Northwest Power and Conservation Council, $248 \mathrm{p}$.

Plummer, E., and Zuckerman, A., 2012, White Salmon River watershed anadromous fish passage inventory 2009-2011 Survey Report: Underwood Conservation District Report, Prepared for Washington Salmon Recovery Funding Board.

Riverbend Engineering, LLC, and JR Merit Industrial Contractors, 2013, Annual sediment assessment report-2013: PacifiCorp Energy, Condit Hydroelectric Project Decommissioning FERC Project No. 2342, 13 p., accessed April 2015, at http://www.pacificorp.com/content/dam/pacificorp/doc/Energy_Sources/Hydro/Hydro_Licensing/Con dit/201309272013AnnualSedimentRptFinalCombined.pdf .

Thompson, K., 1972, Determining stream flows for fish life: Vancouver, Washington, Pacific Northwest River Basin Commission, Vancouver, Washington, p. 31-50.

U.S. Forest Service, 2015, White Salmon Wild and Scenic River: U.S. Forest Service, accessed April, 2015 at http://www.fs.usda.gov/detail/crgnsa/specialplaces/?cid=stelprdb5182064.

U.S. Forest Service, 1991, Final environmental impact statement for the Lower White Salmon National Wild and Scenic River management plan-Columbia River Gorge National Scenic Area, Mt. Hood, Oregon: U.S. Forest Service, accessed November, 2014 at http://babel.hathitrust.org/cgi/pt?id=umn.31951d00621913n\#view=1up;seq=3.

Warrick, J.A., Duda, J.J., Magirl, C.S., and Curran, C.A., 2012, River turbidity and sediment loads during dam removal: EOS, Transactions of the American Geophysical Union, v. 93, no. 43, p. 425426, doi:10.1029/2012EO430002. 
Washington State Department of Ecology, 2007, Condit Dam removal final State Environmental Policy Act (SEPA) supplemental environmental impact statement: Ecology Publication \#07-06-012, Yakima, Washington, accessed November 2014, at http://www.ecy.wa.gov/biblio/0706012.html.

Washington State Department of Ecology, 2015, WRIA 29 Wind-White Salmon: Department of Ecology, accessed April 2015, at http://www.ecy.wa.gov/water/wria/29.html.

Wilcox, A.C., O’Connor, J.E., and Major, J.J., 2014, Rapid reservoir erosion, hyperconcentrated flow, and downstream deposition triggered by breaching of $38 \mathrm{~m}$ tall Condit Dam, White Salmon River, Washington: Journal of Geophysical Research, Earth Surface, v. 110, doi:10.1002/2013JF003073. 
Publishing support provided by the U.S. Geological Survey

Science Publishing Network, Tacoma Publishing Service Center

For more information concerning the research in this report, contact the Director, Western Fisheries Research Center U.S. Geological Survey

6505 NE 65th Street

Seattle, Washington 98115

http://wfrc.usgs.gov/ 
